\title{
Assessment of Character Association in Relation to Growth, Yield and Studies on Various Quality Parameters [Calcium Oxalate Crystals (Raphides), Shelf Life and Starch] in Different Colocasia (Colocasia esculenta L.) Genotypes
}

\author{
Basavaraj Shellikeri", Kiran Malshe, Y.R. Parulekar and N.V. Maskhar \\ College of Agriculture, Dr. Balasaheb Sawant Konkan Krishi Vidyapeeth, Dapoli, \\ Ratnagiri-415712, Maharashtra, India \\ *Corresponding author
}

\begin{abstract}
A B S T R A C T
Colocasia (Colocasia esculenta L.) is an important root crop especially in the humid tropics and sub-tropics. The study was carried out at the "All India Co-ordinated Research Project on Improvement of Tuber Crops", Central Experiment Station, Wakawali during

Keywords

Colocasia, Phenotypic correlation, Genotypic correlation Calcium oxalate, Shelf life, Starch and raphides count per 200 microscopic fields

\section{Article Info}

Accepted:

22 January 2019

Available Online:

10 February 2019

kharif season of the year, 2016 to studied the phenotypic and genotypic associations of herbage yield were significantly positive with all plant height, number of leaves per plant and leaf length. The inter relationship between plant height and petiole length, number of leaves and leaf area were positive and significant at both phenotypic and genotypic levels. And also studies on different colocasia genotypes for calcium oxalate crystals, shelf life and starch content under konkan condition. The presence or absence of micro-character in plant system like calcium oxalate crystals has been used for understanding the palatability of the genotype. The number in calcium oxalate crystals (COCs) and starch content can differ from genotype to genotypes and it might be genetically controlled. We have studied the calcium oxalate crystals in the different plant parts (leaves and petiole), shelf life (leaves) and starch (corm and cormels) among all the colocasia genotypes. The calcium oxalate content in terms of raphide counts per 200 microscopic field was varied from 58.47 to 251.00.The genotype BCC-11 contained less amount of calcium oxalate $\left(40.40 \mathrm{r} 200^{-1}\right.$ $\mathrm{mf}$ ). The starch content was varied from $13.57 \%$ and $24.13 \%$ and significant difference was observed for shelf life of leaves (10.42 to $13.95 \mathrm{hrs)}$ among different colocasia genotypes.
\end{abstract}

\section{Introduction}

Colocasia (Colocasia esculenta L. Schott) also known as 'edode' or 'arvi' is a tropical tuber crop belongs to the monocotyledonous family 'Araceae' of the order Arales whose members are known as 'aroids' (Henry, 2001 and Van Wyk, 2005). Colocasia is believed to have originated in South Central Asia, perhaps in Eastern India or Malaysia (Sturlevant, 1919; Onwueme, 1978 and Watt, 1989). Globally colocasia is cultivated in an area of around 2.0 million ha with an annual production of 12.0 $\mathrm{mt}$ and average yield of $6.5 \mathrm{t} \mathrm{ha}^{-1}$ (FAO STAT, 2010). In the last 5 years (2008-2012), 88 per cent of the area and 78 per cent of the 
production is in Africa. The annual global per capita consumption of colocasia is $1 \mathrm{~kg}$.

Colocasia is importantbecause subsistence food crops are declining gradually leading to wide spread genetic erosion. In the world, it attains a commercial crop status in few countries notably Hawaii, Egypt, Philippines and Caribbean Islands (Alexander, 1969). Despite of limited commercial development, it is important in diet of many people of the world, especially in under developed countries and has a potential as commercial crop for specialty foods. Colocasia is well adapted to shade and can withstand drought to a great extent. The crop is found to thrive well in acidic as well as alkaline soils. Colocasia is one of the tuber crops mainly grown for leafy vegetable under Konkan during kharif season. Colocasia is a rich source of starch and reasonably good source of major components of the diet viz., proteins, minerals and vitamins. All parts of the plant including corm, cormels, rhizome, stalk, leaves and flowers are edible and contain abundant starch (Bose et al., 2003). Among the essential amino acids (those cannot be synthesized in the human body), phenylalanine and leucine are relatively abundant in colocasia. The acridity of tubers and leaves is due to presence of caclium oxalate. Caclium oxalate content in tubers and the leaves varies from variety to variety (Asokan et al., 1980). The oxalic acid content in tubers and leaves plays an important role in consumer's acceptability as tuber and leafy vegetable. The consumer's preference is for the varieties having less acridity.

However, so far not much work towards development of high yielding sutiable types with less calcium oxalate and high starch content has been done in this crop except few attempts of germplasm collection and their evaluation (Plucknett et al., 1970). Hence, it was felt necessary to undertake well planned research work to evaluate suitable genotypes for growth performance and herbage yieldof colocasia as consumer acceptability under hot and humid climate of Konkan region.

\section{Growth parameters}

Sibyala (2013) studied the performance of sixteen different taro (Colocasia esculenta L.) cultivars for growth, yield and quality parameters and reported that the plant height was maximum in IG Collection-8 $(96.23 \mathrm{~cm})$ and minimum was recorded in IG Collection-4 $(58.03 \mathrm{~cm})$. While maximum number leaves (15.47) plant $^{-1}$ were observed in IG Collection-6. Maximum leaf lamina length $(42.97 \mathrm{~cm})$, width $(33.93 \mathrm{~cm})$, petiole length $(75.97 \mathrm{~cm})$ and petiole width $(6.30 \mathrm{~cm})$ was recorded by cultivar CA-21, while minimum in cv. Kasibugga.

Angami et al., (2015) carried out varietal evaluation in taro and reported that 'Panchamuki' recorded significantly highest plant height $(179.33 \mathrm{~cm})$, petiole length $(153.15 \mathrm{~cm})$, petiole breadth $(13.87)$, leaf size $\left(3095.67 \mathrm{~cm}^{2}\right)$ and LAI (1.14).

Surjit and Tarafdar (2015) evaluated taro germplasm at Horticultural research station, BCKV, West Bengal under AICRP on tuber crops and observed variations in all the plant growth characters. They recorded the range of leaf lamina length from $24.34 \mathrm{~cm}$ to $39.41 \mathrm{~cm}$, leaf lamina breadth from $16.17 \mathrm{~cm}$ to 28.57 $\mathrm{cm}$ and length of petiole varied from $44.25 \mathrm{~cm}$ to $76.11 \mathrm{~cm}$.

Bassey et al., (2016) evaluated taro germplasm in AkwaIbom state Nigeria and concluded that there was significant difference among the taro accessions for plant height, no of leaves, leaf area and corm characters. The genotypes 'Oku Abak' exhibited superior performance in plant height, no of leaves, leaf area. While 'Ikot Ada Idem' recorded the 
lowest value for height and no of leaves.

\section{Herbage yield}

With concerned to leafy vegetable colocasia gained less importance over its tuber characters. Most of the studies was carried out with respect to tuber characters even though the leaves of colocasia was economically important as like tuber. So, with this, present study was focused on herbage yield as one objective and base for the feature work.

\section{Quality parameters}

Chadha et al., (2007) recorded that the dry matter percentage of tubers (cormels) was maximum in BCC-10 (29.18\%) and minimum in Telia (23.23\%). Starch (dry weight basis) content was also maximum in the same cultivar BCC- $10(65.7 \%)$ and minimum in the cultivar, Telia. Maximum protein (fresh weight basis) content of fresh tuber was recorded in cultivar, BCC-32 $(0.90 \%)$ and minimum in $\mathrm{BCC}-24(0.70 \%)$.

Hung et al., (2007) reported that starch content of taro corms ranged from $21.1 \%$ to $26.2 \%$ and oxalates from $234 \mathrm{mg}$ to $411 \mathrm{mg}$ $100^{-1} \mathrm{~g}$ dry matter.

Chattopadhyay et al., (2010) studied the nutrient composition of corms of elephant foot yam. Maximum dry matter and starch (fresh weight basis) content was observed by NDA-9 (32.50 \% and $28.70 \%$ ), minimum in Midnapur (17.50 \% and11.75\%). They also noticed that the highest crude protein content was in cultivar Singur $(2.60 \%)$ and the lowest in cultivars Midnapur $(0.84 \%)$, Ranchi (1.01\%), and Bidhan Kusum (1.08\%).

Angami et al., (2015) estimated bio chemical constituent of different taro cultivars and reported that 'Nadia Local' showed highest level of oxalic acid $\left(1.05 \mathrm{mg} 100 \mathrm{~g}^{-1}\right)$, highest dry matter content $(27.50 \%)$ was recorded in cultivars KCA-1 and Panchamukhi, while the highest moisture $(82.83 \%)$ was recorded in IG collection-5.

Saadi and Mondal (2012) studied the calcium oxalate crystals (Raphides and Idioblast) of some selected members of Araceae in Eastern India and reported that two types of calcium oxalate crystal (Type-I and Type-IV). In Amrophophallus campanulatus (Type-IV) having longer crystals and Colocasia esculenta (Type-IV) having shorter crystals.

Surjit and Tarafdar (2015) evaluated taro germplasm at Horticultural research station, BCKV, West Bengal under AICRP on tuber crops and observed variations in starch content $(13.71 \%$ to $18.36 \%)$ and dry matter content of cormels varied from $(22.77 \%$ to $25.46 \%)$.

\section{Materials and Methods}

The experiment was carried out during the period of June to November, 2016 (Kharif season crop) at "All India Co-ordinated Research Project on Improvement of Tuber Crops", Central Experiment Station, Wakawali falls under tropical humid zone with an average rainfall of $3000 \mathrm{~mm}$ is situated at an altitude of $242 \mathrm{~m}$ above MSL. The geographical situation is $17^{0} 48^{\prime} \mathrm{N}$ latitude and $73^{\circ} 78^{\prime}$ E longitude. The experiment was laid out in Randomized Block Design with 16 treatments (genotypes) in 3 replications.

Each plot was measured in $1.35 \times 1.8 \mathrm{~m}$ consisted of three rows with 3 plants per row. Accordingly, 9 plants spaced at $60 \times 45 \mathrm{~cm}$ apart, were accommodated per plot. Observations on morphological characters were recorded at 15, 30, 45, 60 and 75 DAP except days to $1^{\text {st }}$ leaf emergence and herbage yield was recorded at 45, 60 and 75DAP and the procedure for calcium oxalate, shelf life and starch content as follows; 


\section{Calcium oxalate crystals}

Crystals were isolated from both fresh and dry plant specimens. However, dry material was preferred to increase crystal recovery. With the purpose of avoiding potential contamination of crystalline samples by soil particles, plant stems, leaf, petiole, root, corm or storage organ were carefully washed with abundant distilled water. After removal of needles epidermis, thin sections of plant stems, leaf, petiole, root, and corm or storage organ were excised and washed several times. The raphides could be easily separated manually. Clearing technique is used to specifically locate the calcium oxalate crystals in the plant tissue.

Tissue sections were macerated in water and crystals were mechanically freed with the help of dissection knives, segments were fixed in glycerine and water. After that we prepared a slide for observation. The slides were observed under light microscope (10X x 40X) as well as phase contrast microscope (Leica DM-1000) and polarized microscopy for detailed analysis and obtaining better picture as well as measuring the length and breadth of raphide crystal (Saadi and Mondal, 2012).

\section{Starch $(\%)$}

To a known quantity (10 g) of fresh ground sample, little water was added and heated up to $60{ }^{\circ} \mathrm{C}$ temperature. After some time, $100 \mathrm{ml}$ of 95 per cent alcohol was added and centrifuged till the precipitate settled at the bottom. The residue was filtered and washed with 50 per cent alcohol and transferred to a $500 \mathrm{ml}$ stoppered conical flask with $100 \mathrm{ml}$ of distilled water and $20 \mathrm{ml}$ concentrated HCL.

Then the conical flask was kept on boiling water bath for $2 \frac{1}{2}$ hours, cooled and neutralized with $1 \quad \mathrm{~N} \quad \mathrm{NaOH}$ using phenolphthalein indicator and the volume made up with distilled water. This test solution was used for determination of starch (Ranganna, 1977).

$\%$ Starch $=\%$ Reducing sugars $\times 0.90$

\section{Shelf life of leaves}

The harvested leaves of each treatment were kept at ambient temperature $\left(28.4-31.3^{\circ} \mathrm{C}, 80\right.$ $85.7 \% \mathrm{RH}$ ) and shelf life was estimated based on their shrivelling and shrinkage.

\section{Statistical Analysis}

The experimental data were statistically analyzed by following the standard procedures of Panse and Sukhatme (1985).

\section{Results and Discussion}

The results obtained from the present study as well as discussions have been summarized under following heads:

Assessment of character association in relation to growth and herbage yield in different colocasia genotypes

The intensity and direction of the association among the characters may be measured by genotypic $(\mathrm{G})$ and phenotypic $(\mathrm{P})$ correlation depending on the types of material under study.

The estimates of phenotypic and genotypic correlation coefficient (Table 1) depicted that the genotypic correlation were higher than the corresponding phenotypes ones for all the character combinations establishing predominant role of heritable factors.

The phenotypic and genotypic associations of herbage yield were significantly positive with all plant height, number of leaves per plant and leaf length. 
Table.1 Genotypic and phenotypic correlations in herbage yield and related leaves characters

\begin{tabular}{|c|c|c|c|c|c|c|c|c|c|c|}
\hline \multicolumn{2}{|l|}{ Character } & $\begin{array}{l}\text { Plant } \\
\text { height }\end{array}$ & $\begin{array}{l}\text { Petiole } \\
\text { length }\end{array}$ & $\begin{array}{l}\text { Petiole } \\
\text { girth }\end{array}$ & $\begin{array}{c}\text { Leaf } \\
\text { thickness }\end{array}$ & $\begin{array}{l}\text { No. of } \\
\text { leaves }\end{array}$ & $\begin{array}{l}\text { Leaf } \\
\text { length }\end{array}$ & $\begin{array}{c}\text { Leaf } \\
\text { Breadth }\end{array}$ & $\begin{array}{l}\text { Leaf } \\
\text { Area }\end{array}$ & $\begin{array}{l}\text { Herbage } \\
\text { yield }\end{array}$ \\
\hline \multirow{2}{*}{$\begin{array}{l}\text { Plant } \\
\text { height }\end{array}$} & $\mathrm{G}$ & 1.000 & 0.835 & 0.169 & -0.192 & 0.506 & 0.364 & 0.072 & -0.663 & 0.450 \\
\hline & $\mathrm{P}$ & 1.000 & $0.791 * *$ & 0.148 & -0.166 & $0.430 * *$ & $0.299 *$ & 0.059 & $-0.654 * *$ & $0.428 * *$ \\
\hline \multirow{2}{*}{$\begin{array}{l}\text { Petiole } \\
\text { length }\end{array}$} & G & & 1.000 & 0.284 & 0.239 & 0.261 & 0.367 & 0.065 & -0.400 & 0.191 \\
\hline & $\mathrm{P}$ & & 1.000 & 0.268 & 0.227 & 0.221 & $0.334 *$ & 0.057 & $-0.371^{* *}$ & 0.160 \\
\hline \multirow{2}{*}{$\begin{array}{l}\text { Petiole } \\
\text { girth }\end{array}$} & $\mathrm{G}$ & & & 1.000 & -0.026 & 0.125 & 0.489 & 0.460 & 0.270 & 0.293 \\
\hline & $\mathrm{P}$ & & & 1.000 & -0.003 & 0.047 & $0.321 *$ & $0.380^{* *}$ & 0.239 & 0.226 \\
\hline \multirow{2}{*}{$\begin{array}{l}\text { Leaf } \\
\text { thickness }\end{array}$} & G & & & & 1.000 & 0.329 & -0.078 & 0.272 & 0.221 & 0.307 \\
\hline & $\mathrm{P}$ & & & & 1.000 & 0.224 & -0.056 & 0.256 & 0.202 & 0.298 \\
\hline \multirow{2}{*}{$\begin{array}{l}\text { No. of } \\
\text { leaves }\end{array}$} & $\mathrm{G}$ & & & & & 1.000 & 0.437 & 0.087 & 0.484 & 0.980 \\
\hline & $\mathrm{P}$ & & & & & 1.000 & $\begin{array}{c}0.318^{*} \\
*\end{array}$ & 0.004 & $0.411^{* *}$ & $0.822 * *$ \\
\hline \multirow[t]{2}{*}{ Leaf length } & G & & & & & & 1.000 & 0.227 & -0.027 & 0.495 \\
\hline & $\mathrm{P}$ & & & & & & 1.000 & 0.205 & -0.007 & $0.433 * *$ \\
\hline \multirow{2}{*}{$\begin{array}{l}\text { Leaf } \\
\text { breadth }\end{array}$} & G & & & & & & & 1.000 & 0.455 & 0.039 \\
\hline & $\mathrm{P}$ & & & & & & & 1.000 & $0.365^{*}$ & 0.037 \\
\hline \multirow[t]{2}{*}{ Leaf area } & $\mathrm{G}$ & & & & & & & & 1.000 & 0.324 \\
\hline & $\mathrm{P}$ & & & & & & & & 1.000 & 0.037 \\
\hline \multirow{2}{*}{$\begin{array}{l}\text { Herbage } \\
\text { yield }\end{array}$} & $\mathrm{G}$ & & & & & & & & & 1.000 \\
\hline & $\mathrm{P}$ & & & & & & & & & 1.000 \\
\hline
\end{tabular}

P: Phenotypic correlation; G: Genotypic correlation

$*$, **: Significance at $5 \%$ and $1 \%$ probability, respectively 
Table.2 Starch and calcium oxalate content of different colocasia genotypes

\begin{tabular}{|l|l|c|c|c|}
\hline \multicolumn{1}{|c|}{} & $\begin{array}{c}\text { Starch } \\
(\%)\end{array}$ & $\begin{array}{c}\text { Ca Oxalate (Raphide counts per 200 } \\
\text { microscopic field) }\end{array}$ & $\begin{array}{c}\text { Shelf life } \\
\text { (hr) }\end{array}$ \\
\hline $\mathrm{G}_{1}$ & Sanjivini & 18.10 & 239.60 & 11.30 \\
\hline $\mathrm{G}_{2}$ & NDB-9 & 16.70 & 240.13 & 12.18 \\
\hline $\mathrm{G}_{3}$ & M-12-429 & 20.07 & 223.73 & 11.77 \\
\hline $\mathrm{G}_{4}$ & Mahim & 19.37 & 82.73 & 11.38 \\
\hline $\mathrm{G}_{5}$ & DevkibaiWalanga & 17.13 & 113.67 & 11.97 \\
\hline $\mathrm{G}_{6}$ & Sawantwadi & 16.87 & 64.67 & 12.67 \\
\hline $\mathrm{G}_{7}$ & Muktakeshi & 17.57 & 64.73 & 10.92 \\
\hline $\mathrm{G}_{8}$ & Kelva & 13.57 & 104.13 & 11.90 \\
\hline $\mathrm{G}_{9}$ & BCC-11 & 16.93 & 40.40 & 10.42 \\
\hline $\mathrm{G}_{10}$ & M-9-111 & 21.80 & 136.87 & 13.95 \\
\hline $\mathrm{G}_{11}$ & SreePallavi & 17.73 & 229.87 & 12.32 \\
\hline $\mathrm{G}_{12}$ & KhedShiravali & 15.60 & 233.60 & 11.60 \\
\hline $\mathrm{G}_{13}$ & Talsure & 16.87 & 137.87 & 10.90 \\
\hline $\mathrm{G}_{14}$ & Ac-20 & 20.47 & 58.47 & 12.85 \\
\hline $\mathrm{G}_{15}$ & NDB-22 & 24.13 & 251.00 & 10.90 \\
\hline $\mathrm{G}_{16}$ & Khopoli & 14.10 & 87.13 & 11.23 \\
\hline & Mean & $\mathbf{1 7 . 9 4}$ & $\mathbf{1 3 9 . 1 3}$ & 11.77 \\
\cline { 2 - 5 } & SEm $( \pm)$ & 0.77 & 22.97 & 0.41 \\
\hline & CD $(\mathbf{P}=\mathbf{0 . 0 5})$ & 2.24 & 66.34 & 1.19 \\
\hline
\end{tabular}

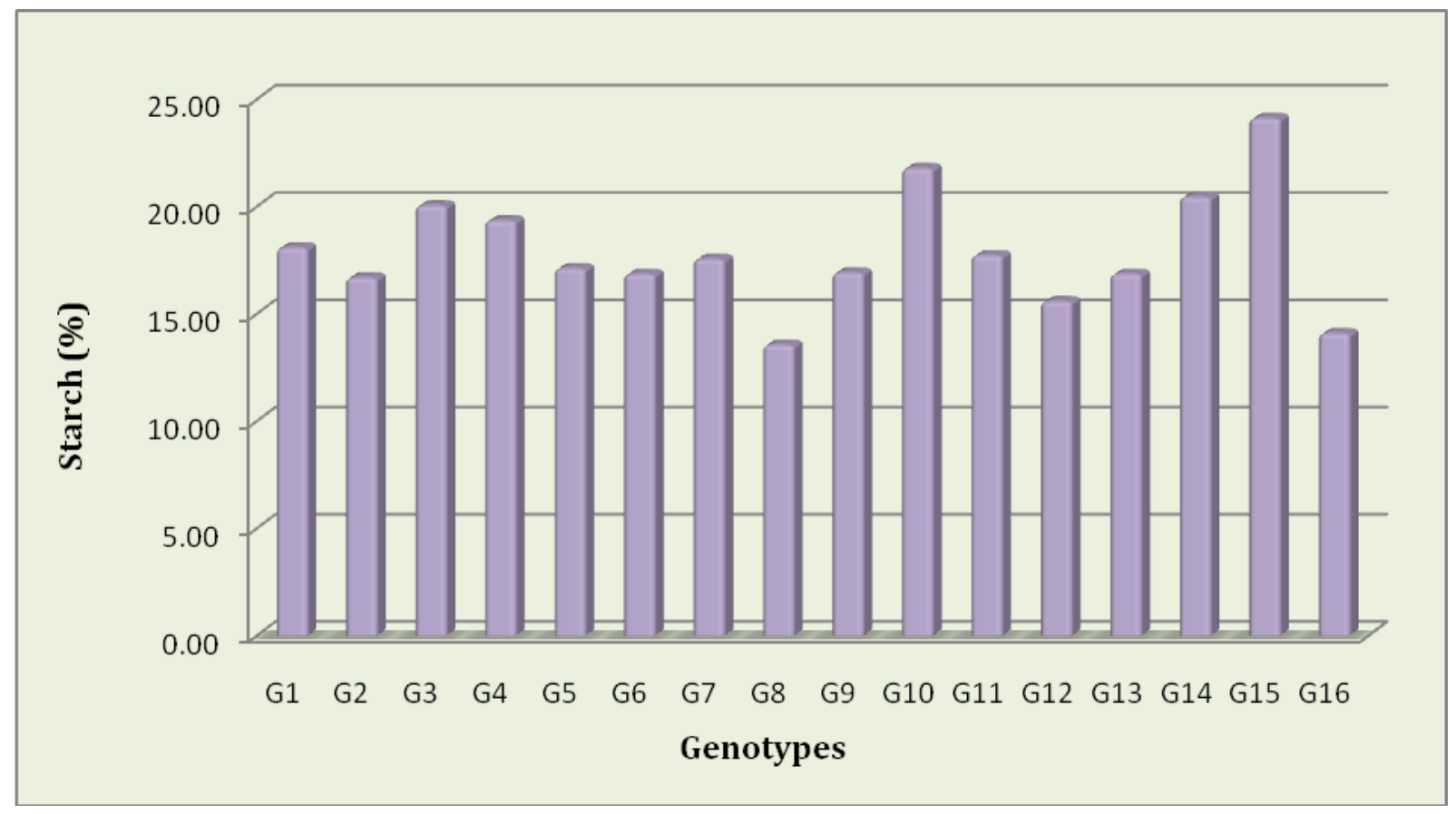

Fig.1 Starch content in different colocasia genotypes 


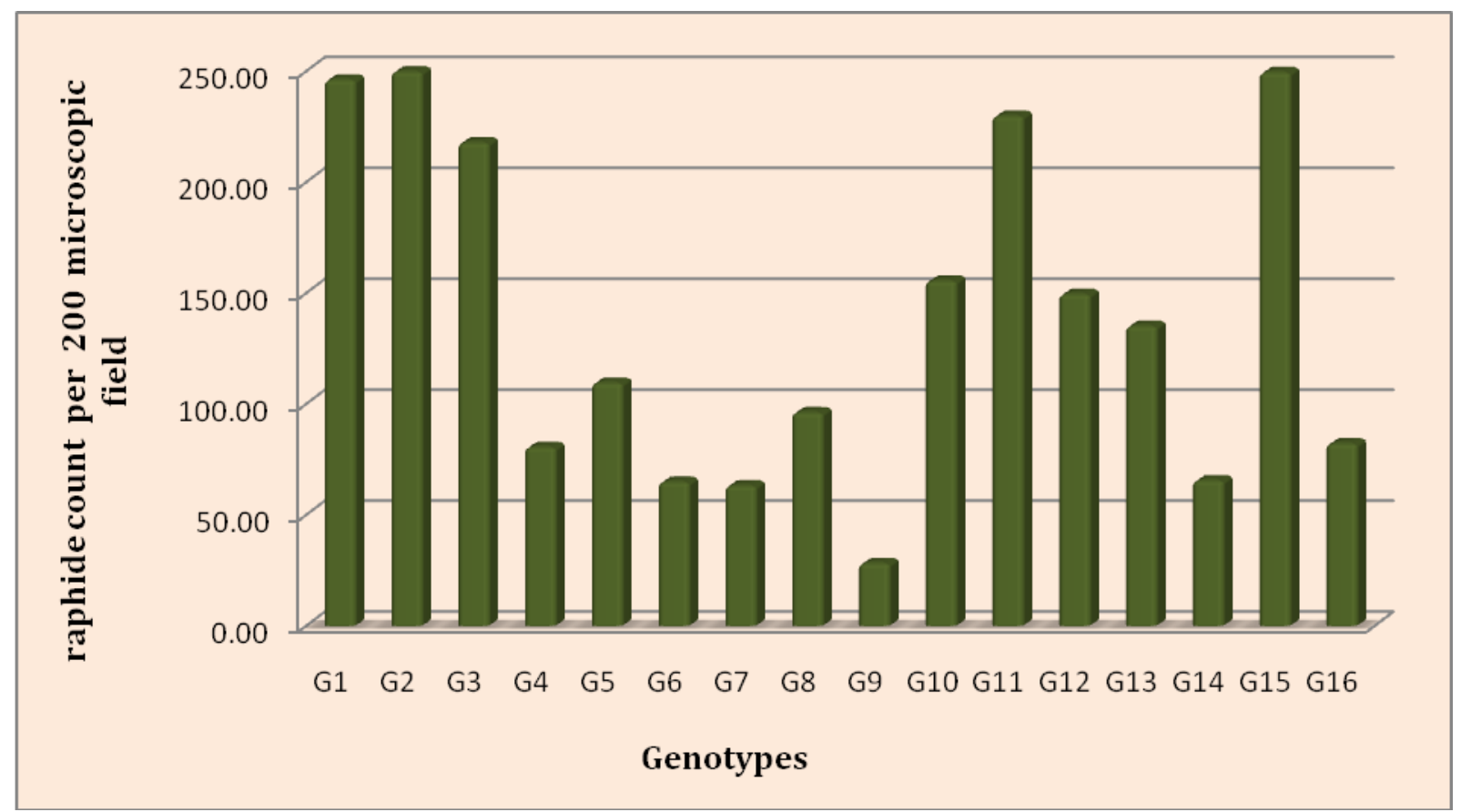

Fig. 2 Calcium oxalate content in different colocasia genotypes

The inter relationship between plant height and petiole length, number of leaves and leaf area were positive and significant at both phenotypic and genotypic levels. Similarly, petiole length, number of leaves per plant and leaf breadth conferred positive and significant correlation with leaf area at both the levels. These findings were consonance with Mohankumar et al., (1990), Thankamma et al., (1995) and Mukherjee et al., (2016). Highly significant positive correlation between herbage yield and number of leaves per plant might be assigned to more vegetative growth from the cormel of the colocasia genotypes.

\section{Studies on various quality parameters}

Calcium Oxalate (Raphide counts per 200microscopic field)

Significant differences were noticed with respect to calcium oxalate content in different colocasia leaves and petiole among all the colocasia genotypes (Table 2 and Figure 1). The calcium oxalate content in terms of raphide counts per 200 microscopic field was varied from 58.47 to 251.00. Higher amount of calcium oxalate content $\left(251.00 \mathrm{r} \mathrm{200^{-1 } \mathrm { mf } )}\right.$ was found in the NDB-22 genotype and it was at par with NDB-9 (240.13 $\left.\mathrm{r} \mathrm{200^{-1 }} \mathrm{mf}\right)$, Sanjivini (239.60 r 200 $\left.{ }^{-1} \mathrm{mf}\right)$, KhedShiravali $(233.60$ r 200-1 mf), SreePallavi (229.87 r 200$\left.{ }^{1} \mathrm{mf}\right)$ and M-12-429 (22.373 r 200-1 $\left.\mathrm{mf}\right)$. While, less amount of calcium oxalate $(40.40$ r $200^{-1} \mathrm{mf}$ ) was found in the genotype BCC11.Libert and franceschi (1987), Ejoh et al., (2006) and Temesgen et al., (2016) also observed similar variation in ca oxalate content. The concentrations of oxalate in plants are influenced by environmental and biological factors, fertilizer application, light intensity, plant variety and genotype. The oxalate content in taro leaves is a major factor to consider when different Genotypes of taro are recommended for human or animal 
consumption (Hang et al., 2017). The acridity of colocasia is related to calcium oxalate content and less acridity is preferred for consumption.

\section{Starch $(\%)$}

Significant differences were noticed with respect to starch content in different colocasia corm and cormels among all the colocasia genotypes (Table 2 and Figure 2). The starch content was varied from $13.57 \%$ and 24.13 $\%$. Higher amount of starch content $(24.13 \%)$ was recorded in NDB-22 followed by M-9$111(21.80 \%)$. While, less amount of starch was found in the genotype Kelva (13.57\%) followed by Khopoli (14.10 \%). Awasthi (2000), Santosa et al., (2002), Sen et al., (2006) and Chattopadhyay et al., (2010) observed similar range of variations in starch content among different taro genotypes. Surjit and Tarafdar (2015) observed variations in starch content $(13.71 \%$ to $18.36 \%)$.

\section{Shelf life of leaves (hr)}

The data on the shelf life of the leaves of different colocasia genotypes are presented in Table 2. It is seen that there was a significant difference among the colocasia genotypes and in the range of 10.42 to $13.95 \mathrm{hrs}$. The maximum shelf life (13.95 hr) was observed in M-9-111 and it was at par with AC-20 $(12.85 \mathrm{hr})$. While, the lowest shelf life (10.42 hr) was recorded in BCC-11 genotype. Chauhan (2016) also observed the variations in shelf life content in indigenous genotypes of water spinach. The shelf life and keeping quality of different colocasia genotypes is related to the moisture content in leaves and respiration rate.

Thus, it indicated the variation in moisture, starch and Calcium oxalate content which is the most important qualitative character for the crop improvement in colocasia.
From the correlation study, it is evident that if the plant height, leaf length and number of leaves are increased, the herbage yield per plant will be increased as well. Other characters were shown nullified effect through direct and indirect effect. This helps to reduce undesirable direct indirect effects in order to make use of only concerned characters for selection.

With respect to quality parameters, BCC-11, NDB-22 were found to be superior for quality parameters based on the palatability. All these parameters of genotypes should be tested for two to three seasons for valid conclusion. These genotypes can be recommended for commercial cultivation as a leafy vegetable during kharif in the Konkan region.

\section{References}

Alexander, M. N. 1969. Some factors affecting the demand of starchy roots and tubers in Trinidad. Proc. Int. Symp. Trop. Root Crops, Trinidad. 2 (5): 4546.

Angami, T., Jha, A. K., Buragohain, J., Deka, B. C., Verma, V. K. and Nath, A. 2015. Evaluation of Taro (Colocasia esculenta. L) Cultivars for growth, yield and quality attributes. Journal of Hort. Sci. 10 (2): 183-189.

Asokan, P. K., Hassan, M. A. and Neelkumar, P. N. 1980. Quality attributes of colocasia. Agric. Res. J. Kerala. 18 (1): $102-103$.

Awasthi, C.P. 2000. Biochemical composition and nutritive value of corm collections of edible aroids of Himachal Pradesh. Indian Journal of Horticulture. 57 (1): 75-82.

Bassey, E. E., Umoh, G. S., Ndeayo, N. U., Nneke, N. E. and Akpan, G. U. 2016. Investigations into taro [Colocasia esculenta (L.) Schott] leaf blight outbreak and identification of resistant 
cultivars in Akwa Ibom State, Nigeria. Int. J.Curr.Res.Biosci.Plant Biol. 3 (5): $137-143$.

Bose, T. K, Kabir, J, Maity, T.K. Parthasarathy, V.A. and Som, M.G. 2003. Vegetable crops, vol 2. NayaUdyog Publishers, Kolkata. pp: 413-442.

Chattopahyay, A., Saha, B., Pal, S., Bhattacharya, A. and Sen, H. 2010. Quantitative and qualitative aspects of elephant foot yam. InternationalJournal of Vegetable Science. 16: 73-84.

Chauhan, H. 2016. Collection, evaluation and characterization of indigenous genotypes of water spinach. Thesis submitted to Indira Gandhi Krishi Vishwavidyalaya, Raipur.

Ejoh, A. R., Mbiapo, F. T. and Fokou, E. 2006. Nutrient composition of the leaves of colocasia of taro (Colocasia esculenta) and the fruits of Solanum melongena. Plant Foods for Human Nutrition, 49: 107-112.

FAOSTAT. 2010. FAO Statistical Database. http://faostat.fao.org.

Hang Du Thanh, Hai Phan Vu, Hai Vu Van, Nagoan Le Duc, Tauc Le Minh and Geoffrey Savage 2017. Oxalate content of Taro leaves grown in central Vietnam. Foods. 6: 2-8.

Henry, R. J. 2001. Plant genotyping: The DNA fingerprinting of plants. $\mathrm{CAB}$ Publishing, Southern Cross University, Australia.

Libert, B. and Franceschi, V. R. 1987 Oxalate in crop plants. J. Agrico. Food Chem. 35: 926-938.

Mohankumar, C. R. Saraswathy, P. and Sadanandan, N. 1990. Correlation and path coefficient analysis on yield and yield components in taro. Journal of Root Crops. 16: 140-43.

Mukherjee, D., Roquib, Md. A., Das, N. D. and Mukherjee, S. 2016. A Study on Genetic Variability, Character
Association and Path Co-Efficient Analysis on Morphological and Yield Attributing Characters of Taro [Colocasia esculenta (L.) Schott]. American Journal of Plant Sciences, 7 : $479-488$.

Onwueme, I. C. 1978. The tropical tuber crops: yams, cassava, sweet potato, cocoyams. John Wiley and Sons, New York.

Panse, V.G. and Sukhatme, P.V. (Revised by Sukhatme, P.V. and Amble, V.N.) 1985. Statistical methods for agricultural workers. ICAR, New Delhi.187-202.

Plucknett, D. L., De la Pena, R. S. and Obero, F. 1970. Taro (Colocasia esculenta). A Review of Field Crop Abstract 23: 413426.

Ranganna, S. 1997. Manual of Analysis of fruit and vegetable products. Tata McGraw Hill Publishing Company Ltd., New Delhi.

Saadi, Sk. Md. and Mondal. A. K. 2012. Studies on the Caclium oxalate crystals (Raphides) and Idioblast of some selected members of Araceae in Eastern India. African Journal of Plant Science Vol. 6 (9): 256-269.

Santosa, E., Sugiyama, N., Muhamad, A. C., Lontoh, A. P., Sudiatso, S., Kawabata, S., Hikosaka, S., Sutoro and Ahmad, H. 2002. Morphological and nutritional characterization of elephant foot yam in Indonesia. Japanese Journal of Tropical Agriculture. 46 (4): 265-271.

Sen, H. Chattopadhyay, A. and Pal, S. 2006. Characterization of swamp taro landraces of eastern India. The Horticultural Journal. 19 (2): 107-110.

Sibyala, S. 2013. Thesis title-Studied the performance of sixteen different taro [Colocasia esculenta (L.) Schott] cultivars for growth, yield and quality parameters. Department of Vegetable Science, Horticulture College and 
Research Institute, Dr. Y.S.R. composition of taro (Colocasia Horticultural University. esculenta L.). International J. of Food Sturlevant, E.L. 1919. Note on edible plants. Res. N.Y. Agric. Expt. Stn. 69 (70): 185186.

Surjit, M. and Tarafdar, J. 2015. Diversity in Morpho-Biometrical characters, Nutritional facts and Isozymes activity of Indian landraces of upland Taro (Colocasia esculenta var. antiquorum L. Scott). International Journal of Tropical Agriculture 33 (2): 1163-1166. Temesgen, M., Retta, N. and Tesfaye, E. 2016. Effect of pre-curding on nutritional and anti-nutritional Sci. and Nutrition. 1 (1): 5-11.

Thankamma, P. B. K. and Sreekumari, M. T. 1995. Varietal improvement of Taro. Annual Report CTCRI, Trivendrum, pp: 45-46.

Van Wyk, B. E. 2005. Food plants of the world: Identification, culinary uses and nutritional value. Briza Publications, Pretoria, South Africa.

Watt, G. 1989. Dictionary of the economic plants of India. Supt. Govt. Printing, Calcutta. 2: 509-513.

\section{How to cite this article:}

Basavaraj Shellikeri, Kiran Malshe, Y.R. Parulekar and Maskhar, N.V. 2019. Assessment of Character Association in Relation to Growth, Yield and Studies on Various Quality Parameters [Calcium Oxalate Crystals (Raphides), Shelf Life and Starch] in Different Colocasia (Colocasia esculenta L.) Genotypes. Int.J.Curr.Microbiol.App.Sci. 8(02): 3363-3372.

doi: https://doi.org/10.20546/ijcmas.2019.802.391 